\title{
CONTEMPORARY CHANGES IN THE ETHNIC STRUCTURE OF THE POPULATION IN THE AUTONOMOUS PROVINCE OF KOSOVO AND METOHIJA
}

\author{
SAŠA MILOSAVLJEVIĆ ${ }^{\mathbf{1}}$, JOVO MEDOJEVIĆ ${ }^{\mathbf{1}}$ \\ ${ }^{1}$ Faculty of Sciences, University in Priština - Kosovska Mtrovica, Kosovska Mtrovica, Serbia
}

\begin{abstract}
Twenty years (1999 - 2019) after the end of the conflict in the Autonomous Province of Kosovo and Metohija, it can be stated that nowhere in Europe is there such ethnic segregation of the population as is the case with the AP of Kosovo and Metohija. Following the withdrawal of pumped security forces from the entire territory of Kosovo and Metohija and the entry of the United Nations peacekeeping force into the Serbian Autonomous Province, Kosovo Albanians carried out their persecution from Kosovo through terrorist attacks on Serbs and other nonAlbanian populations (Montenegrins, Gorans, Roma, Ashkali) carried out their persecution from Kosovo and Metohija and fundamentally changed the ethnic structure of the Province. An insight into the majority of 223.081 exiles and displaced persons from Kosovo and Metohija indicates an exodus against the Serbs. The number of displaced Roma, Ashkali and Egyptians is estimated at about 100.000. The mass persecution of the Serb and other non-Albanian populations has resulted in tremendous changes in the ethnic structure of the Province, which today, with $93 \%$ of the total population, is dominated by Albanians, while other ethnic communities have a participation of $7 \%$.
\end{abstract}

Keywords: Population, Ethnicity, Kosovo and Metohija.

\section{INTRODUCTION}

Contemporary demographic determinants indicate that today the territory of the Autonomous Province of Kosovo and Metohija is dominated by the ethnic Albanian community. Since June 1999, the violent expulsion, killings, threats, pressures of various kinds exposed to the Serb and other non-Albanian populations have resulted in a change in the ethnic structure of the population of Kosovo and Metohija. After the end of the confl ict in Kosovo and Metohija, 223,081 refugees have left this territory, with 206,879 taking refuge in Serbia and 16,202 in Montenegro. This total of refugees does not include the displaced Roma, Ashkali and Egyptians, although estimates suggest that 100,000 of them have been displaced from Kosovo and Metohija. Only from the province's capital, Priština, 23.000 Serbs, 6.000 Roma, 1.000 Muslims and 1.000 Turks fled. Nowhere in the present-day world has such severe ethnic cleansing of cities and villages been recorded as has been the case with the Serbs and Serbian settlements in Kosovo and Metohija. The large urban centers of Kosovo and Metohija such as Priština, Prizren, Peć, Đakovica, Uroševac, Gnjilane, Podujevo, Vučitrn and southern Kosovska Mitrovica are inhabited exclusively by Albanians. The Serb and other nonAlbanian populations remained in rural areas where they still formed the majority, and for which the name "enclaves" became established. From June 15. 1999 to May 10. 2003 a total of 110 Orthodox churches and monasteries was burned, plundered and

destroyed. The same tendencies have continued to this day, along with the desecration of cemeteries, stoning and burning of the returnees' homes (Medojević \& Milosavljević, 2019a).

\section{MATERIAL AND METHODS}

The metodology in this paper is according to the subject, objectives and tasks of the research. The historical method contents the use of literature, written documents and other archive material and presents us knowledge about the demography past of the Kosovo and Metohija. Data were collected in public institutions and in the Statistical Office of the Republic of Serbia and Statistical Office of Kosovo. It should be emphasized that the 1991 census boycotted the entire Albanian, part of the Roma and part of the Muslim population, and that the 2011 census boycotted the Serb population. According to the United Nations Resolution, the census in Kosovo and Metohija can only be conducted by United Nations representatives. Despite this, the Priština authorities organized a census with the help of Eurostat (European Statistical Office), Italian Istat (Istituto Nazionale di Statistica), Swedish Sida (The Swedish International Development Cooperation Agency), UNFPA (The United Nations Population Fund) as well as the country: United Kingdom, Switzerland and Luxembourg. The census was conducted from April $1^{\text {st }}$ to April 15 $5^{\text {th }}, 2011$ in 34 municipalities, without the municipalities in the north part of Kosovo and Metohija, where the majority are Serbs: Leposavić, Zubin Potok, Zvečan, and northern Kosovska Mitrovica (Milosavljević \& Punišić, 2011). 


\section{ANALYSIS OF CHANGES IN THE TOTAL POPULATION MOVEMENT OF AUTONOMUS PROVINCE KOSOVO AND METOHIJA FROM 1948 TO 2019}

The population of Kosovo and Metohija has been growing steadily in the second half of the $20^{\text {th }}$ century. We attribute the increase in total population to the demographic boom of the Albanian population above all. The total population of Kosovo and Metohija grew from 727.820 in 1948 to 1.954 .747 in the 1991 census, an increase of $168 \%$ (Table 1). Despite all the expectations and forecasts of the last twenty years, the total population of Kosovo and Metohija has been in a slight decline and according to the last census from 2011 the population is 1.739.825, which is a decrease of $12 \%$ compared to 1991 (Medojević et al., 2011).

Not all ethnic communities have participated equally in increasing Kosovo's population. While the Albanian population had all the characteristics of a population boom, the Serb and other non-Albanian populations were in regression (Radovanović, 2004).

Table 1. Movement of total population of the Autonomous Province Kosovo and Metohija by Censuses 1948-2011.

\begin{tabular}{|c|c|c|c|c|c|c|c|}
\hline Year & 1948. & 1953. & 1961. & 1971. & 1981. & 1991. & 2011. \\
\hline Population & 727.820 & 808.141 & 963.988 & 1.243 .693 & 1.584 .411 & 1.954 .747 & 1.739 .825 \\
\hline
\end{tabular}

Table 2. Ethnical structure of population of the Autonomous Province Kosovo and Metohija by Censuses 1948-1991 (Statistical Office of the Republic of Serbia).

\begin{tabular}{|c|c|c|c|c|c|c|}
\hline & 1948. & 1953. & 1961. & 1971. & 1981. & 1991. \\
\hline Albanians & 498.242 & 524.559 & 646.805 & 916.168 & 1.226 .736 & $1.607 .690^{*}$ \\
\hline Serbs & 171.911 & 189.869 & 227.016 & 228.264 & 209.498 & 195.301 \\
\hline Montenegrins & 28.050 & 31.343 & 37.588 & 31.555 & 27.028 & 20.045 \\
\hline Muslims & 9.679 & 6.241 & 8.026 & 26.357 & 58.562 & 57.408 \\
\hline Roma & 11.230 & 11.904 & 3.202 & 14.593 & 34.126 & 42.806 \\
\hline Turks & 1.315 & 34.583 & 25.784 & 12.244 & 12.513 & 10.838 \\
\hline Croats & 5.290 & 6.201 & 7.251 & 8.264 & 8.717 & 8.161 \\
\hline Others & 2.103 & 3.541 & 8.316 & 6.248 & 7.260 & 12.498 \\
\hline TOTAL & 727.820 & 808.141 & 963.988 & 1.243 .693 & 1.584 .441 & 1.954 .747 \\
\hline
\end{tabular}

*estimated population

When looking at the censuses after the Second World War, we notice that the number of Serbs in the territory of Kosovo and Metohija increased from 1948 to 1971, when it reached its maximum. The Serb population increased by 56.353 during this period (Table 2). For the next twenty years there has been a continuous decline in the total number of Serbs in Kosovo and Metohija, so the 1981 census recorded 209.498 Serbs, while according to the 1991 census there were 195.301. Thus, the participation of the Serbian population in the total population from $23,6 \%$ in 1948 dropped to $9,9 \%$ in the 1991 census (Medojević \& Milosavljević, 2019b).

The movement of the Montenegrin national minority over the same period has a similar tendency. The number of Montenegrins increased from 28.050 in 1948 to 37.588 in 1961, when it reached its maximum. Since 1961, the number of Montenegrins has been steadily declining, and in 1991 it was 20.045. The participation of the Montenegrin population in Kosovo and Metohija decreased for 8.005 inhabitants from 1948 to 1991 , respectively their participation in the national structure decreased from $3,9 \%$ to $1 \%$ in the same period.

After Second World War, the Albanian population increased. From 1948 to 1991, their number increased threefold, from 498.242 to 1.607.690. Albanian participation in the ethnic structure of the population of Kosovo and Metohija increased from $68,4 \%$ in 1948 to $82,2 \%$ in 1991. During the 1960s and 1980 s, the increase in the number of Albanians in Kosovo and Metohija had the characteristics of a population boom. The census period 1961-1971, determined the increase in the number of Albanians from 646.605 to 916.168 (a total increase of 269.563 or $42 \%$ ); in the period 1971-1981. the number of Albanians increased from 916.168 to 1.226 .736 (a total increase of 310.568 or $34 \%$ ), and in the period 1981-1991. their number increased from 1.226.736 to 1.607 .690 (a total increase of 380.954 or $31 \%$ ). The causes of the population boom of the Albanian population in the second half of the twentieth century, in Kosovo and Metohija, can be found in the prolongation of life expectancy, falling mortality rates of adults and infants with stagnant birth rates.

The participation of the Muslim and Roma populations in Kosovo and Metohija in the second half of the $20^{\text {th }}$ century varied from census to census. Globally, their numbers and participation in population structure have increased. The Roma population increased by 31.576 (from 11.230 in 1948 to 42.806 in 1991), respectively the participation of the Roma population in the total population increased from $1,5 \%$ to $2,2 \%$. The growth of the Muslim population was even more pronounced. In 1948, the number of Muslims was 9.679 (participation in the total population at $1,3 \%$ ), and in 1991 their number was 57.408 
(participation in the total population at 2,9\%) (Medojević \& Milosavljević, 2015).

\section{CONTEMPORARY ETHNIC DETERMINATES IN THE AUTONOMUS PROVINCE OF KOSOVO AND METOHIJA}

After the end of the aggression against the Federal Republic of Yugoslavia in June 1999, organized terror of the Albanian population over the Serb and other non-Albanian population resulted in forced migration movements of Serbs, Montenegrins, Roma, Ashkali, Egyptians into central Serbia and Montenegro, which completely disrupted ethnic structure of the Province. Today, twenty years after the end of the aggression and the entry of international forces into the territory of Kosovo and Metohija, there is still speculation about the total number of population as well as the ethnic structure of the population. The information obtained from the 2011 census may be considered irrelevant. Their irrelevance is reflected, first and foremost, in the quantitative values that determine the ethnic composition of the population, especially the Serb community, which boycotted the census in all four municipalities in the north of the province, while Serb turnout in the areas south of the Ibar River was below $50 \%$. During the census, the Serb population was exposed to threats, pressures and blackmail.

Table 3. Ethnical structure of population of the Autonomous Province Kosovo and Metohija by Census 2011 (Statistical Office of Kosovo).

\begin{tabular}{|c|c|c|}
\hline Ethnicity & Number & $\%$ \\
\hline Albanians & 1.616 .869 & 92,9 \\
\hline Serbs & 25.532 & 1,5 \\
\hline Turks & 18.738 & 1,1 \\
\hline Bosniaks & 27.533 & 1,6 \\
\hline Roma & 8.824 & 0,5 \\
\hline Ashkali & 15.436 & 0,9 \\
\hline Egyptians & 11.524 & 0,7 \\
\hline Gorans & 10.265 & 0,6 \\
\hline Others & 2.352 & 0,1 \\
\hline Undefined & 912 & 0,1 \\
\hline It is not known & 1.840 & 0,1 \\
\hline TOTAL & 1.739 .825 & 100 \\
\hline
\end{tabular}

Based on the results of the census, the most numerous ethnic communities in Kosovo and Metohija were Albanians with 1.616 .869 inhabitants, which participate with $92,9 \%$ of total population of Kosovo and Metohija (Table 3). The majority of the population was Albanian in all municipalities, except eight municipalities (four in northern Kosovo and Metohija: Leposavić, Zubin Potok, Zvečan and northern Kosovska Mitrovica and four newly formed municipalities: Mamuša, Gračanica, Ranilug and Parteš). An equal number of Albanians and Serbs were in the municipalities of Novo Brdo, Štrpce and Klokot.
The number of Serbs in this census was only 25.532 with participation of $1,5 \%$ in the total population. However, the Serbian population in the area of Kosovo and Metohija is much larger and therefore its participation in the total population is larger. The estimated number of Serbs in the four municipalities in the north of the Province is 60.000 , while in the interior of Kosovo and Metohija there are more than 50 ethnically purely Serb or mixed settlements in which Serbs are represented in significant numbers.

About 40.000 Serbs live in central Kosovo. Thus, the Serbian settlements in the municipality of Vučitrn: Gojbulja, Prilužje and Grace. The Serb enclaves in Priština municipality are: Gračanica, Laplje selo, Čaglavica, Badovac, Preoce and Sušica. In the municipality of Obilić, it is Plemetina, and in the municipality of Kosovo Polje: Batuse, Ugljare, Bresje and Kuzmin. The Serb enclaves in Lipljan municipality are: Dobrotin, Livađe, Donja Gušterica, Gornja Gušterica, Suvi Do, Staro Gracko and Novo naselje. Prekovce is a Serbian enclave in Novo Brdo municipality. About 2.100 Serbs live in the Metohija settlements (the Goraždevac enclaves near Peć and Velika Hoča near Orahovac). In the municipality of Istok these are: Osojane, Crkolez, Dobruša, Banja, Ljubovo and Žač. Banja and Suvo Grlo are enclaves in Srbica municipality, and Vidanje in Klina municipality. Kosovo's pomoravlje is home to 35.000 Serbs. Thus, in the municipality of Gnjilane, the Serb population lives in the villages of: Šilovo, Pasjane, Parteš, Koretište, Donja Budriga, Stanišor, Kusce, Straža, Kmetovce and Poneš, and in Kosovska Kamenica in the villages of Ranilug, Ropotovo and Donje Korminjane. In the municipality of Vitina in the villages: Klokot, Vrbovac, Trpeza, Požaranje, Novo selo, Žitinje and Binač. In the far south of the AP Kosovo and Metohija, about 12.000 Serbs live in the Šara-mountain enclaves. They are located in the municipality of Strpce in the following villages: Berevce, Brezovica, Viča, Vrbeštica, Gotovuša, Donja Bitinja, Drajkovce, Jažince, Sevce and Sušiće (Milosavljević, 2013). Demographic data indicate that there are currently approximately 149.100 Serbs in the entire area of Kosovo and Metohija, accounting for about $8,5 \%$ of the total population. Contemporary demographic determinants also point to the problem of the erasure of certain nationalities (Montenegrins, Muslims, Yugoslavs, Macedonians) and the formation of new ones (Bosniaks, Ashkali, Egyptians). Thus, according to the 2011 census, there are no Montenegrins at all, up to 30.000 according to earlier censuses. All this can lead us to conclude that Montenegrins have declared themselves either as Serbs, or have emigrated or are categorized as "Others", "Undefined" or "It is not known" with a total population of 5.104. This phenomenon points to the malicious tendency of the provisional Kosovo authorities to erase, all the parameters that determine the Serb ethnicity and the existence of the Serbian national being in the territory of Kosovo and Metohija. 
Table 4. Population of Kosovo and Metohija by ethnicity by municipalities and cities, 2011, Census of population (Statistical Office of Kosovo).

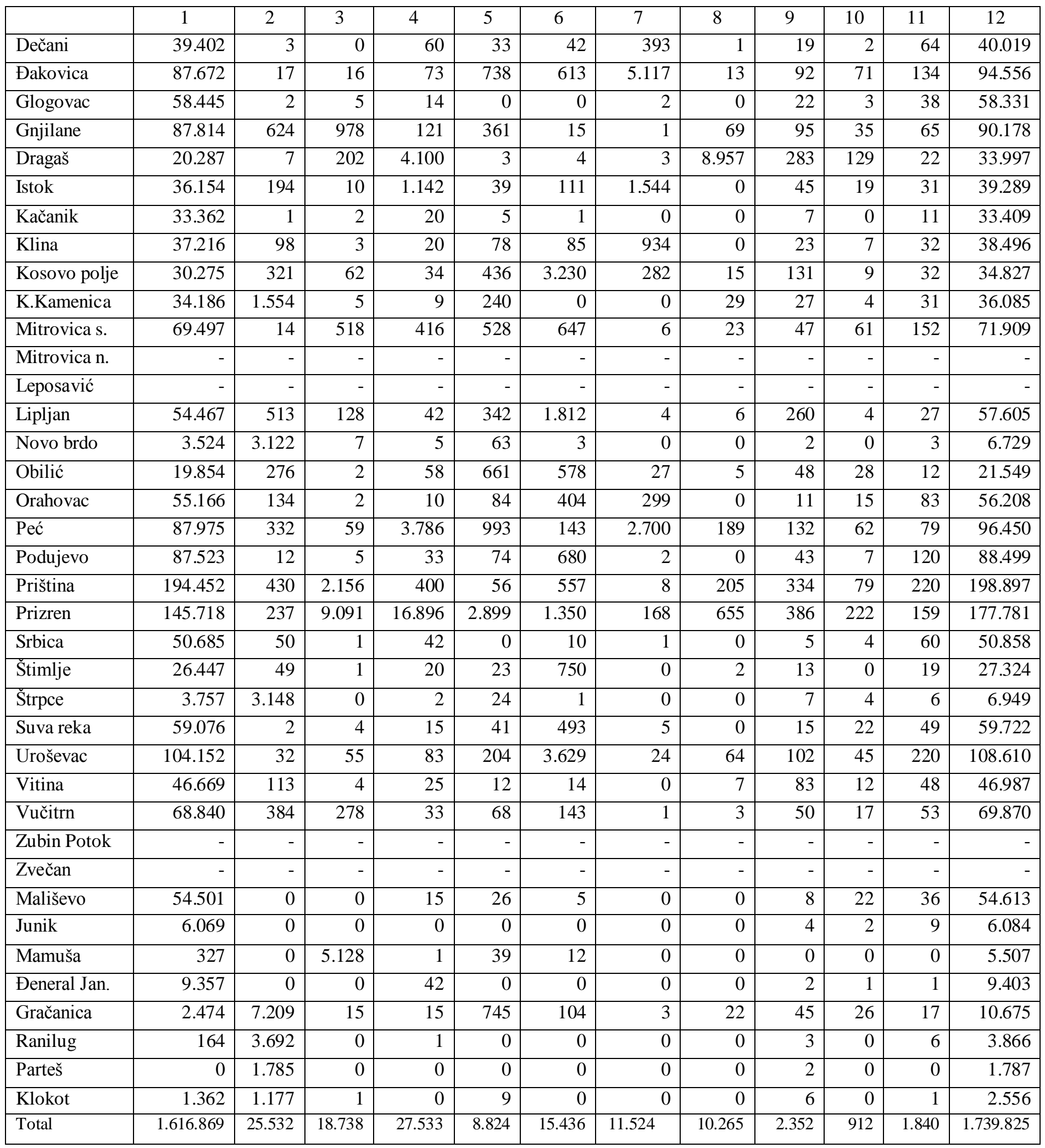

Legend: 1-Albanians, 2-Serbs, 3-Turks, 4-Bosniaks, 5-Roma, 6-Ashkali,

7-Egyptians, 8-Gorans, 9-Others, 10-Undefined, 11-It is not known, 12-Total 
The number of Bosniaks was 27.553 with participation from $1,6 \%$ of the population of Kosovo and Metohija. The most represented were in the Prizren municipality with 16.896 inhabitants, with participation from $9,5 \%$ of the municipal population. In addition to Prizren, a significant number also lived in the municipalities of Dragaš, Peć and Istok.

The population of Turks was 18.738 or $1,1 \%$ of the total population. Most of them, 93,1\% were in the newly formed municipality of Mamuša, but a more serious number of them lived in the municipalities of Prizren, Priština and Gnjilane.

Ashkali had a population of 15.436 with participation in the total population of $0,9 \%$. Significant number were the municipalities of Kosovo Polje (9,3\%), Uroševac, Prizren and Lipljan.

The Egyptian ethnic minority numbered 11.524 with a total population participation of $0,7 \%$. They were most concentrated in the municipalities of Đakovica, Peć and Istok.

Gorans ethnic minority population was 10.265 , or $0,6 \%$ of the total population of Kosovo and Metohija. Most Gorans people lived in Dragaš municipality, 8.957 or $26,3 \%$ of the municipality population. The municipalities of Prizren, Priština and Peć also made significant numbers (Table 4).

Unlike earlier censuses conducted by the Republic of Serbia in the territory of the AP Kosovo and Metohija, in the 2011 census, there are no definitions for "Muslims", "Yugoslavs" and "Macedonians", which are ethnic communities that were represented until 1999 in considerable numbers. In this way, we remain deprived of comparative analyzes, monitoring of the number of the said ethnic communities as well as their participation in the total population of the Province.

\section{CONCLUSION}

The analysis of changes in the total population movement of the AP Kosovo and Metohija, during the second half of the $20^{\text {th }}$ century, indicate a constant increase of the population. At the same time, with the increase of population, there are changes in the ethnic structure. The Albanian population is constantly increasing, while the Serb population is declining. Since June 1999, due to organized Albanian terror against Serbs and other non-Albanian populations, an exodus of about 320,000 people has occurred. The Serb population was expelled from all urban areas while a smaller number was held in rural areas, making up the so-called Serb enclaves. The results of the 2011 census conducted by (temporary Kosovo institutions) in Kosovo and Metohija cannot be considered relevant. Irrelevance is reflected in the inability to comprehensively understand the total population and their ethnic determinants. The Serb population did not respond to the census in the north of the Province, while in other parts it partially responded. The irrelevance of the census is also reflected in the fact that the census does not include citizens who are temporarily living abroad. Also, no displaced persons (Serbs and Montenegrins) were enumerated.
The Roma community formally divided the pre-war divisions into Roma, Ashkali and Egyptians, and Bosniaks into Bosniaks, Muslims, and Gorans. Incorrectly conducted census and inexperience of training of census, takers determine the 2011 census data to be irrelevant, having only one purpose, namely, to the detriment of Serbs and the Serb community that has lived on the territory of AP Kosovo and Metohija for centuries.

\section{REFERENCES}

Medojević, J., \& Milosavljević, S. 2019a. Demografski procesi na Kosovu i Metohiji od 1999. do 2019. godine, Kosovskometohijski zbornik 8, Srpska akademija nauka i umetnosti, Beograd, pp. 265-285.

Medojević, J., \& Milosavljević, S. 2019b. Geo-demografski procesi na Kosovu i Metohiji od 1999. do 2019. godine, Zbornik rezimea sa Međunarodnog naučnog skupa „Nauka bez granica 3“, Filozofski fakultet Univerziteta u Prištini sa privremenim sedištem u Kosovskoj Mitrovici, Kosovska Mitrovica, pp. 126-127.

Medojević, J., \& Milosavljević, S. 2018. Značaj geografskih determinanti u funkciji održivog opstanka srpske zajednice na Kosovu i Metohiji, Međunarodni tematski zbornik „Nauka bez granica“, Knjiga 4 Vreme i prostor, Filozofski fakultet Univerziteta u Prištini sa privremenim sedištem u Kosovskoj Mitrovici, Kosovska Mitrovica, pp. 251-266.

Medojević, J., \& Milosavljević, S. 2015. Posledice progona stanovništva sa Kosova i Metohije od 1999. do 2015. Godine, Zbornik radova (Knjiga 1) sa Četvrtogsrpskog kongresa geografa sa međunarodnim učešćem „Dostignuća, aktuelnosti i izazovi geografske nauke i prakse“ povodom 150 godina rođenja Jovana Cvijića, Geografski fakultet Beograd, Srpsko geografsko društvo, Beograd, pp. 357-362.

Medojević, J., Pavlović, M., \& Milosavlević, S. 2011. Demograhic analysis of forced migrations in Kosovo and Metohia from 1999 to 2011, Global Modern Demographic problems: migration and emigrational policy, Russian Academy of Sciences, Russian State University for the Humanities, Moscow, pp. 124-135.

Milosavljević, S. 2013. Demografsko-ekonomska analiza stanja $\mathrm{u}$ srpskim enklavama u funkciji unapređivanja strateškog razmišljanja i delovanja na Kosovu i Metohiji, Zbornik radova sa Međunarodnog naučnog skupa „Kulturno nasleđe Kosova i Metohije, istorijske tekovine Srbije na Kosovu i Metohiji i izazovi budućnosti“, Knjiga 2, Kancelarija za Kosovo i Metohiju Vlade Republike Srbije, Univerzitet u Prištini sa privremenim sedištem u Kosovskoj Mitrovici, Beograd, pp. 885-894.

Milosavljević, S., \& Punišić, M. 2011. Popis stanovništva na Kosovu i Metohiji 2011. godine - između relevantnosti i irelevantnosti, Zbornik radova sa Trećeg kongresa srpskih geografa, Geografsko društvo Republike Srpske i PMF Uiverziteta u Banja Luci, Banja Luka, pp. 395-399.

Radovanović, M. 2004. Etnički i demografski procesi na Kosovu i Metohiji, Liber Press, Beograd

Statistical Office of Kosovo

Statistical Office of the Republic of Serbia 